\title{
Cultural tourism: topical issues in the context of cultural and historical memory
}

\author{
Tatiana L. Kashchenko ${ }^{1}$, and Irina V. Polozhentseva ${ }^{2}$ \\ ${ }^{1}$ Financial University under the Government of the Russian Federation, GSP-3, Leningradsky \\ prospect, 49, 125993 Moscow, Russia \\ ${ }^{2}$ K. G. Razumovsky Moscow State University of Technologies and Management (First Cossack \\ University), Zemlyanoy Val, 73, 109004 Moscow, Russia
}

\begin{abstract}
The authors follow up the issues of cultural tourism in their relationship with cultural and historical heritage in the context of education of young people. The methods of cultural and historical analysis, forecasting, method of expert assessment, sociological methods are used at the article. Emphasizing the importance of cultural heritage in the globalizing world, the authors consider it as a factor of collective identity formation, which is important for national stability and safety ensuring. In the authors' opinion the absolute demand for the preservation of cultural and natural heritage for future generation with awareness of not only economic but social benefit of its preservation should be the long-term strategy of modern cultural policy in the Russian Federation. They focus on objects of city architecture and the urban environment as triggers of cultural memory and territorial (local) identity. Based on the opinion poll data among first-year students of K. G. Razumovsky Moscow State University of Technologies and Management (FCU) the authors highlight the main issues of updating cultural and historical heritage as a means of young people education: the formation of young people's interest in the history of the culture of their region and the country as a whole; providing of the assess to cultural values; education of careful attitude towards cultural and natural monuments, respect for the authenticity and diversity of cultural values of Russia and mankind; training in anti-vandal nondestructive behavior; involving in active participation of protection of cultural heritage monuments; popularization of tourism culture among the younger generation including the development of a training system for organizers of youth tourism (volunteers).
\end{abstract}

\section{Introduction}

In the globalizing world of the 21 st century the historical heritage has become the most important value. The past, an authentic thing has gained not only a cultural, but a political and economic value. Thousands of people go on journey every year to discover foreign cultures, enjoy authentic things, learn more about architecture, art, lifestyle in the country of visit. And this gives a high-power impulse to the development of cultural tourism that in turn becomes the main resource for the development of regions and the entire countries. 
According to the WTO experts cultural tourism today accounts 18 to $25 \%$ of the inbound tourist flow, and this share will grow in the future.

The purpose of the work is to identify the topical issues of cultural tourism in the context of cultural and historical memory and its role in the upbringing of young generations.

Research tasks:

- to assess cultural and historical heritage as the most important factor of the nation identity formation based on the common of culture and cultural and historical memory;

- to elicit dialectical interconnection of the cultural tourism cultural and historical heritage and the government policy of heritage protection;

- to consider the cultural heritage role in the upbringing of young people (by the example of K. G. Razumovsky Moscow State University of Technologies and Management (First Cossack University), hereafter K. G. Razumovsky MSUTM (FCU)).

Since the $80 \mathrm{~s}$ of the XX century a special term denoted a special kind of tourism cultural tourism has appeared in the humanitaristics. UNESCO considers cultural tourism as a particular type of tourism, "paying respect to the other nations' cultures", contributing honor, recipiency and keen insight of the wealthy variety of the cultures of our world [1]. International Council on Monuments and Sites (ICOMOS) Charter defines cultural tourism as a form of tourism aiming among other goals "the discovery of monuments and sites", "learning of the national culture of the country of visit" [2]. In Russia the term "cultural and educational tourism" being the Russian analogue of English-language one is used more active. In this way the following determination is given in "Russian Federation strategy of tourism developing until 2035": "cultural and educational tourism" is a journey with educational purposes that acquaints a tourist with historical and cultural and natural values, traditions and customs by excursion activities and events" [3]. The global mission of cultural tourism is the dialogue and protection of cultures, as well as the rapprochement of nations, prevention of conflict and impatience, promotion of respect and tolerance [4]. Cultural tourism aiming to imbue the minds of youth with patriotism and civic consciousness is of no less importance for the Russian citizens themselves.

Cultural tourism is considered not as an abstract cultural value, but as a real economic and managerial category in the works of V.E. Gordin, B.V. Emelyanova, A.V. Kvartalny, E.A. Kotlyarova, S.A. Krasnaya, E.V. Moshnyaga, O.V. Rakhmaleva, V.V. Khariton, P.S. Shirinkina etc. However, in our opinion, this "victorious" trend of economic determinism may carry risks for the preservation and protection of cultural heritage. It is necessary to understand that on the one hand cultural tourism is in the closest and most interdependent relationship with the unconditional requirement of preserving the cultural and natural heritage for the future generations and on the other hand with the awareness of its not merely economic, but social benefits.

\section{Materials and methods}

Cultural and historical analysis is applied to understand the dynamics of regional and national historically significant systems in the context of the study of cultural and historical heritage in its relation to the modern life. The forecasting method reveals the harmfulness and tragic nature of inattention to cultural and historical heritage as the main risk for the development of cultural tourism. The method of expert judgement presupposes first of all taking into account the opinions of representatives of the architectural community, urbanists, cultural scientist, art historians, restorers. The method of a questionnaire survey is applied to obtain data as regards of young people to the problems of historical heritage in Moscow.

The obtained data provide the material for the formation of the University educational and research program. 


\section{Discussion results}

In September 2019 a fundamental document about tourism "Russian Federation strategy of tourism developing until 2035" with justly noted the economic role of tourism was released. On 65 pages of the Strategy the factors and possible risks of tourism development on the territory of the Russian Federation are considered in detail. It is emphasized that the expected economic return from the development of international and domestic tourism is hampered by the lack of tourism infrastructure, institutional obstacles, negative stereotypes etc. In this regard, the Strategy proposes a whole range of measures to accelerate the development of tourism, including tourism management improving, creating digital services for cultural and educational tourism, investing in the modernization and renewal of existing infrastructure, tax remissions and many other things [3].

However, the list of measures to increase the competitiveness of Russia as a center of tourism doesn't contain a thing which in our opinion should be the main one. The list practically doesn't say about what in fact should be the heart of the recognition and attractiveness of any place on Earth - its identity, expressed through the authenticity of cultural and historical objects. In other words, practically nothing is said about the cultural and historical heritage.

It is our strong conviction that among the internal risks of tourism development the most significant one is just insufficient attention to the preservation of the historical heritage as the most important factor in the attractiveness of the visiting country. However, it is cultural and historical objects, authentic witnesses and real agents of the past in the present that create the main points of attraction for both international and domestic travel. People go to the places where the authenticity of the culture is maintained. Rome would not be a Mecca of international tourism if its center was built up with modern multistorey buildings and shopping centers.

Russia is traditionally perceived as a country that has made a huge contribution to world culture - UNESCO recognizes 20 World Heritage Sites that gives it number 10 in the global ranking. Among them are the Moscow Kremlin and Red Square, the Church of the Ascension in Kolomenskoye, the ensemble of the Novodevichy Monastery, the architectural ensemble of the Trinity-Sergius Lavra, the historical center of St. Petersburg, historical monuments of Veliky Novgorod, the white-stone architectural monuments of Vladimir and Suzdal, the Solovetsky historical and cultural complex, Kizhi and others [5]. At the same time, the total number of monuments in Russia is more than 85 thousand!

Russian experts write about the need to find a golden mean between satisfying the mass interest in visiting such places, the economic and social development on the ground and the need to preserve the cultural values inherent in these places [6]. But in our opinion it is necessary to turn this structure over so that the horse stands in front of the cart but not vice versa. In this case, the golden maxim of tourism will look like this: to preserve cultural values inherent in places of tourist attraction including for the formation of this attraction. And from that moment on to create the infrastructure conducive for economic and social development on the ground and to regulate the possibilities of satisfying the mass interest in visiting such places. In other words, the economic benefits of cultural tourism can only be achieved if cultural heritage sites are carefully preserved. That is why the unconditional preservation of the heritage today for tomorrow must be a priority.

\section{Cultural and historical heritage}

Cultural heritage is a part of the material and spiritual culture created by past generations and handed down to the future as something valuable and revered. An object of cultural heritage is a place, construction (creature), complex (ensemble), their parts, territories or 
water bodies linked with them, other natural, naturally anthropogenic or man-made objects regardless of their state of preservation, which have brought to our time the value from anthropological, archaeological, aesthetic, ethnographic, historical, scientific or artistic point of view and preserved their authenticity [7]. The cultural heritage created by past generations is something that has unconditional universal value for humanity and for every country. Moreover, the value of the cultural heritage only increases over time.

Russia in the global world of the XXI century must elaborate a competitive model of national and cultural identity that would represent the world-widely universal and localnational significance of its culture. Today, elements of the local look especially valuable against the background of the global as well as elements of the unique do against the background of the massive. Many countries are experiencing a boom of the past. Memory studies specialist P. Nora writes about the renewed attachment to "heritage" - what is called "heritage" in the English-speaking world, and "patrimoine" in France: "the world is flooded with surging wave of remembrance, firmly combining loyalty to the past (real or imagined) with a sense of belonging, with collective consciousness and individual self-awareness, with memory and identity" [8]. Reflecting the peculiarities of the nation cultural identity the cultural and historical heritage is a non-renewable resource for the nation. Loss of it means irrecoverable damage that no imitation will ever save. According to E. Renan "a nation is a soul, a spiritual principle. Two things, which are essentially one, make up this soul, this spiritual principle ... One of them is the common possession of a rich heritage of memories, the other one is a common agreement, the desire to live together, continue to use collectively the inheritance fallen undivided" [9].

Such a model of national and cultural identity requires the new Government cultural policy. "Government cultural policy framework" says: "The goals of Government cultural policy are preservation of the historical and cultural heritage and its use for upbringing and education. Strengthening of civic identity is associated with the increasing role of cultural heritage sites, preserving the historical environment of cities and settlements, including small towns; creating conditions for the development of cultural and educational tourism" [10]. Unfortunately, in reality, these goals are not achieved.

The role of cultural and historical heritage includes as follows:

— the basis of cultural identity for a nation, group, individual;

— institution of education of patriotism and citizenship of young generations;

- a factor contributing to the cultural adaptation of migrants;

- the marker of attraction for tourists from all over the world who value authenticity and cultural identity.

We have already investigated the mechanisms of actualizing of historical memory before by referring to the biography of older generations in the family [11-12], in this regard, another type of social memory is considered - cultural memory, which is formed through the perception of monuments of cultural and historical heritage.

The focus on architectural monuments of cultural and historical heritage is due to the fact that, in our opinion, they are the main triggers of memory. Each of us without noticing it has a special territorial (local) identity. It is based on visual images of houses and streets familiar from childhood. Such topographic images-memories become socially significant and turn into cultural social memory. Living in one city, region, village, people realize their unity, regardless of social, property, ethnic differences. At the same time, territorial identity can be acquired anew by moving to another city or region.

Moscow has the strongest attraction in the Russian Federation. And this is natural. A huge capital city where the main financial, cultural, and labor resources are concentrated. In this regard the interviews with famous young actors and musicians, many of whom arrived in the capital several years ago are indicative. When asked about their favorite places in Moscow everyone calls its old districts: Patriarch's, Chistye Prudy, Sretenka, Arbat lanes. 
There is probably no need to prove why this is so. Cultural memory is conservative by nature, it does not like and fears changes. Culturologist K.E. Razlogov writes: "Spiritual culture is based on memory, on the fact that connections, customs and traditions uniting people should be as stable as possible, otherwise mutual understanding will be destroyed. Therefore culture from this point of view is the enemy of these changes, even if they were made on some more reasonable basis than the one on which they exist now" [13]. A huge problem in the Russian city (not only in Moscow) is that the territorial identity of new generations turns out to be largely flawed. Massive low-cost estate development of cities made them faceless, uninteresting, scarce for awakening high-quality cultural memory. The situation wisely reflected by E. Braginsky and E. Ryazanov, the screenwriters of the film "The Irony of Fate, or Enjoy Your Bath", is actually not funny at all.

The role of the architectural environment in the formation of a person is enormous. Our perception of the world, mood, work capacity largely depends on the quality of the environment. The dismal mass estate development has very little to do with true culture. The dormitory districts of standard industrial estate development in Moscow, St. Petersburg, Yekaterinburg, Rostov and all without exception more or less large Russian cities cannot, by definition, be the place to attract tourists. But even more dangerous is the construction of high-rise buildings in the area of the historic city center. Even if they were built according to excellent designs, although in most cases new high-rise buildings have no architectural value. They not only erase the individuality and originality of historical Russian cities, but destroy the fragile world of the preserved past, which means they deprive future generations of joy [14]. Moreover, the architectural environment is the most democratic, free resource for visual enjoyment. Where the interests of economic agents prevail over the interests of building protection, there will be no reason for the development of cultural tourism, even if there are excellent hotels and Michelin-starred restaurants.

Old Moscow is under the knife. The Department of Cultural Heritage churned out the removal of protection status from buildings of the XIX even XVIII century [15]. "It's hard to believe it," writes Rustam Rakhmatullin, a culturologist and Moscow expert, "but one day we may wake up in a city where instead of living history there will be an invented story, a quasi story, a story similar - and always - not real" [16]. As a result Moscow was not included in the list of historic cities. One of the principles of the modern Government cultural policy should be the priority of the society's right to preserve the material and intangible cultural heritage of Russia over the property interests of individuals and legal entities.

Cultural tourism, cultural and historical heritage and youth education. The preservation of the historical landscape is the main condition for the preservation of cultural and historical memory, and this, in turn, is a component of patriotic education. For young people visual observation, familiarization, cultural and educational tourism, participation in the protection of monuments means not just an active civic position, but maintaining contact with generations lived earlier. Ignorance of culture, disrespect for the objects of our cultural and historical memory makes us vulnerable to the imposition of alien cultural values from the outside and weakens the general cultural identity of the nation. However, "heritage becomes a real sociocultural fact only if it is transmitted, assimilated, that is, actualized" [17].

Actualization of cultural and historical heritage as a mechanism for educating of young generations includes the following:

- the formation of young people's interest in the history of the culture of their region, the country as a whole;

— providing access to cultural values;

- fostering respect for cultural and natural monuments, respect for the authenticity and diversity of cultural values of Russia and mankind; 
— training anti-vandal non-destructive behavior;

- involving in active participation in the protection of cultural heritage monuments;

- the popularization of the culture of tourism among the younger generation, including the development of a training system for organizers of youth tourism (volunteers).

The idea of continuity, respect for the authenticity of the cultural heritage is given paramount importance at the K. G. Razumovsky Moscow State University of Technologies and Management (First Cossack University). All first year students studying "Design" must participate in the development and implementation of cultural and educational projects [18].

We have conducted a study to find out how young people relate to cultural and historical heritage. How closely is the idea of its value perceived? What is the cultural competence of students Muscovites and those who came from other regions? How does cultural tourism help in the development of cultural and historical heritage? These and other questions were involved in the survey conducted among first and second year students.

Let us illustrate the survey using two questions as an example.

Respondents gave the following answers to the question "Which of the following statements is the most consistent with your attitude towards the monuments of historical heritage"? "I agree with the complete change of the city's appearance, if only it would be comfortable to live there"- $15 \%$; "I want something to remain intact for the next generations and undergo a change when we learn to handle cultural heritage more carefully" - 83\%; "It's difficult for me to answer" - 2\%; "I'm not interested in this topic at all" - $0 \%$. This shows that the overwhelming majority of students recognize the value of cultural and historical heritage.

The question "How would you yourself assess your cultural competence?" was asked at the beginning of the training in cultural and educational design and before the spring session. The dynamics of self-esteem, demonstrated during the comparison of responses, is indicative (Table 1).

Table 1. Dynamics of students' self-esteem in the process of participation in the development and implementation of cultural and educational projects.

\begin{tabular}{|c|l|c|c|}
\hline № & \multicolumn{1}{|c|}{ Answer options } & $\begin{array}{c}\text { At the beginning } \\
\text { of the study }\end{array}$ & $\begin{array}{c}\text { At the end of } \\
\text { the study }\end{array}$ \\
\hline 1. & $\begin{array}{l}\text { My cultural competence is sufficiently } \\
\text { formed }\end{array}$ & 23 & 19 \\
\hline 2. & $\begin{array}{l}\text { I need to work on myself a little more to } \\
\text { form cultural competence }\end{array}$ & 47 & 43 \\
\hline 3. & $\begin{array}{l}\text { I need to learn a lot in order to form } \\
\text { cultural competence }\end{array}$ & 27 & 4 \\
\hline 4. & $\begin{array}{l}\text { I do not consider this competence } \\
\text { necessary for work and life. }\end{array}$ & 8 & 4 \\
\hline
\end{tabular}

Analysis of the data in the table shows that the project activities of students in the cultural and educational sphere motivates them to a deeper study of the cultural and historical heritage of their country and forms an awareness of the importance of its preservation.

\section{Conclusion}

One of the main principles of the modern Government cultural policy should be the priority of the society's right to preserve the tangible and intangible cultural heritage of Russia over 
the property interests of individuals and legal entities. The destruction of monuments of cultural and historical heritage should be considered as the destruction of cultural identity, the forcible imposition of new cultural images.

Cultural tourism is considered as a segment where the cultural identity and cultural memory of new generations are formed. The actions of the state in the sphere of Government cultural policy should be addressed primarily to the young generation of Russian citizens.

The formation of the cultural needs of young people is a complex sociocultural process, in which actualization of cultural memory through the formation of young people's interest in the history of the culture of their region, the country as a whole is of particular importance as well as providing access to cultural property; fostering a respectful attitude towards cultural and natural monuments, respect for the authenticity and diversity of cultural values of Russia and mankind; training in anti-vandal behavior; involving in active participation in the protection of cultural heritage monuments; popularization of the culture of tourism among the younger generation, including the development of a training system for organizers of youth tourism (volunteers).

\section{References}

1. UNESCO Declaration of Tolerance. 1995 year, 9 (1996)

2. Charter for Cultural Tourism of November 9, 1974 (1996)

3. Strategy for the development of tourism in the Russian Federation for the period up to 2035. Order of the Government of the Russian Federation of September 20, 2019 No. 2129-r.

4. E. V. Moshnyaga Scientific works of the Moscow University for the Humanities, 55, 128 (2005)

5. T. N. Mironova, Preservation of cultural and natural heritage, 18 (2005)

6. Cultural tourism: convergence of culture and tourism on the threshold of the CAHI century, 143 (2001)

7. Federal Law No. 73-FZ of June 25, 2002 (as amended on 03/09/2016) "On cultural heritage sites (historical and cultural monuments) of the peoples of the Russian Federation»

8. P. Nora, Emergency ration, 2, 62 (2005)

9. Cultural memory in the context of the formation of the national identity of Russia in the KSHI century, 29 (2015)

10. Fundamentals of state cultural policy. Decree of the President of the Russian Federation of December 24, 2014 No. 808

11. I. V. Polozhentseva. T. L. Kashchenko, Power, 12, 42 (2014)

12. E. V. Aralova, T. L. Kashchenko, I. V. Polozhentseva, O. A. Moiseeva, S. Yu. Sigaev, Espacios. 39(49), 15 (2018)

13. Cultural memory in the context of the formation of the national identity of Russia in the KSHI century, 11 (2015)

14. V. Yu. Zhilenko, Ser.\&Tour.: Cur. Chal., 10(3), 55 (2016)

15. S. Danilova, Great changes await Moscow. comparable to the 1930s

16. R. Rakhmatullin, Tinsel cannot hide dying monuments

17. E. N. Selezneva, Observatory of culture, 1, 86 (2004) 
18. L. Zh. Karavanova, S. E. Shishov, T. M. Rozhnova, K. S. Rozhnova, I. V. Polozhentse va, L. P. Lobacheva., Univ. y Soc., 12(2), 380 (2020) 